\title{
Agenda Empowerment of People in Tarmizi Taher Point of View
}

\author{
Mawardi $^{1}$, Hasyimsyah ${ }^{2}$, Amroeni Drajat ${ }^{2}$ \\ ${ }^{I}$ Ph.D Student in State Islamic University of North Sumatera (UINSU), Medan, Indonesia \\ ${ }^{2}$ Lecturer in State Islamic University of North Sumatera (UINSU), Medan, Indonesia \\ mawardijuned@gmail.com
}

\begin{abstract}
This study aims to explore agenda empowerment of people in Tarmizi Taher point of view. Tarmizi Taher in his book harmony of religious life and study of religions, that religious harmony can be formed by supporting harmonious religious communities, it is necessary for clerics, da'i (preachers), priests, priests and other religious leaders to instill to people about the inevitability of religious pluralism in social life. That the diversity of religions is a fact that cannot be denied. So the consequence is that every religious community has an obligation to recognize and respect other religions, without the need to elevate or demean a religion. The result shows that in Tarmizi Taher's view, community empowerment can be done by providing skills education conducted by the government so that people can compete with the advancement of science and technology.
\end{abstract}

Keywords: Agenda empowerment; Islam; Tarmizi Taher; point of view.

\section{Introduction}

In the perspective of Islamic theology about the harmony of life between religions and the consequences between religious believers, it is closely related to two things, namely, first, relating to Islamic doctrine about the relationship between humans and the relationship between Islam and other religions, second, related to human historical experience itself in relation to the religions embraced by humanity.

Tarmizi Taher in his book harmony of religious life and study of religions, that religious harmony can be formed by supporting harmonious religious communities, it is necessary for clerics, $d a{ }^{\prime} i$ (preachers), priests, priests and other religious leaders to instill to people about the inevitability of religious pluralism in social life. That the diversity of religions is a fact that cannot be denied. So the consequence is that every religious community has an obligation to recognize and respect other religions, without the need to elevate or demean a religion.

From these principles, the pattern of religious life that will develop is a religious attitude that is tolerant and willing to respect other religious communities. This assumption is based on a thought that one's compulsion towards one's religion has been preceded by a mature thought. The existence of religious diversity in social life makes him must make choices on existing religions. When a person makes a choice based on his rationality, he naturally takes responsibility for his choice. The choice of a religion is usually more a legacy of the religion that has been adopted by his family. Problems faced by religious people generally arise when holding a religion different from that adopted by their families.

Normatively, Islam, for example, provides guidance on kindness, not only doing good to fellow Muslims, but also applies to non-Muslims.

Harmony of religious life is a social condition in which all religious groups can live together without reducing their basic rights to carry out their religious obligations. Each lives as a good religious adherent in a state of harmony and peace. Therefore, the harmony of religious life cannot possibly be born from blind fanaticism and ignorance of the religious 
rights and feelings of others. But it does not have to mean that harmony in religious life is based on syncretism because it will cause chaos and damage the value of religion itself.

Harmony in religious life can only be achieved if each group acts gracefully to one another. And the grace of religious life will have meaning for the life and progress of plural society, if it is manifested in mutual restraint toward the teachings, beliefs and habits of other different religious groups, which may be contrary to one's own teachings, beliefs and habits, then attitudes of mutual respect the right of others to truly embrace the teachings of their religion and mutual trust in the good faith of other religious groups. In religious harmony there must be an effort to understand the teachings and religious beliefs of others and also efforts to express their own religious beliefs as wisely as possible not to offend other religious beliefs and there is an attitude to help each other in social activities to overcome mutual backwardness, mutual learning from the advantages and strengths of other parties so that an exchange of experiences occurs to achieve mutual progress. ${ }^{1}$

\section{Review of Literature}

\subsection{Definition of Religious Harmony}

Harmony between religions is one of the main pillars in maintaining the national unity and sovereignty of the Republic of Indonesia. Harmony is often interpreted as a condition of life and life that reflects an atmosphere of peace, order, peace, prosperity, respect, respect, esteem, tolerance, mutual cooperation in accordance with the teachings of religion and Pancasila personality.

The word harmony comes from the Arabic ruknun, the plural word is arkaan which means principle, foundation or foundation. Whereas in Indonesian the meaning of harmony is:

A. Rukun (nominal), means: Something that must be fulfilled for the validity of the work, such as the invalidity of humans in prayer that is not sufficiently conditional, and the principle of harmony, which means the basis or joint: everything is done well does not deviate from the harmony of religion.

B. Rukun (adjective) means: Good and peace are not in conflict: we should live in harmony with neighbors, unite, agree. Reconcile means: reconcile; unite hearts. Harmony: about living in harmony; get along well; agreement: harmony live together.

\subsection{Harmony is the duty of every religion.}

Harmony itself is not a final value, but only a means that must exist as a "conditio sine qua non" to achieve further goals, namely a safe and peaceful situation. This situation is needed by all parties in society to enable the creation of spiritual and mental values that are equally needed to achieve a higher level of life.

Live in an atmosphere where harmony is inevitable. Live in a closed society inhabited by one group adhering to the same religion, but in a modern society, where communication in life together with other religious communities can not be denied, for the sake of the preservation and progress of the community itself. ${ }^{2}$ Living in a plurality society, both in terms

\footnotetext{
${ }^{1}$ TarmiziTaher, Aspiring for the Middle Path: Religious Hrmony in Indonesia. (Jakarta: CENSIS, 1997), p. 9.

${ }^{2}$ D.Hendropuspito,SosiologiAgama,(Yogyakarta;Kanisius,2000), p. 170
} 
of their beliefs and culture, is mutually sustainable to create a religious society that creates a harmonious spirit in order to create an area into a place where plurality is not an issue, and even makes a minority as a supporter for the continued progress of the region.

Therefore, maintaining and even preserving harmony in religious life is a demand of every religion, every religion has no command to make people of different faiths as enemies rather than the religion they profess.

\subsection{Guidelines for Religious Harmony}

Indonesia is a pluralistic country. Such plurality is a gift, but it can also potentially cause problems if not managed properly. one of the problems related to the diversity of the Indonesian people is in terms of religious life. Harmonization between internal or internal religious communities in Indonesia is very important because religion for the community is a value reference system which is the basis for behaving and acting for its adherents.

There are several guidelines that are used to establish harmony among religious communities in the community;

\section{A. Mutual Respect}

Every religious community must or is obliged to cultivate, preserve and increase his beliefs. By strengthening the faith, each religious community will respect each other more so that the feeling of fear and suspicion grows more and more together with increasing piety, suspicion can be eliminated. Mutual respect also includes instilling sympathy for the progress achieved by other groups, so as to be able to arouse optimism with fair competition.

B. Religious Freedom

Every human being has the freedom to embrace a preferred religion and the conditions and conditions provide equal opportunity for all religions. In describing freedom, there is a need for sociological considerations in the sense that in reality the process of socialization based on territory, heredity and education also influences one's religion.

\section{Accept Others}

Every religious community must be able to accept someone as he is with all the advantages and disadvantages. Seeing people of other religions not with their religious perceptions. A Christian accepts the presence of Muslims as they are and vice versa. If you accept Muslims with the perception of Christians then it will not be harmonious but will only sharpen the conflict.

d) Positive Thinking

\subsection{The Role of Government in Fostering Religious Harmony}

In order to achieve harmony and create harmony, as well as harmony between religious believers. The government is taking concrete steps to establish a tri-religious harmony program. With the various rules and decisions set by the government to regulate religious life in Indonesia in the following way:

\section{A. Dialogue Between Religious Believers}

Steps in achieving harmony between religious believers, the way of "dialogue" is one of the methods taken to bring them closer, so that religious believers understand and try to recognize each other's parties.

The purpose of dialogue is that something positive is not negative, that is giving information and values that are owned, then asking other parties to make decisions that can be accounted for. Dialogue between religious believers is a meeting between two or more 
followers of different religions, in which there is an exchange of values and religious information of each party to achieve a form of cooperation in the spirit of harmony. ${ }^{3}$ Interfaith dialogue is a meeting of hearts and minds between adherents of various religions aimed at achieving truth and cooperation on issues faced together.

\section{Discussion}

The figure of Tarmizi Taher is a figure who has an important contribution in all aspects of national and state life. Although widely known as a former military, intelligence figure, former minister of religion, but he transcends all fields of science he is engaged in. His contribution to the empowerment of the people is never doubted because it is proven by real work in alleviating the problem of poverty and inequality that occurs in the midst of society.

Tarmizi Taher is a unique national figure and is difficult to find a substitute, because he works on almost all lines of life of this nation. No wonder that the figure of Tarmizi Taher is always missed by everyone who has worked together or those who admire his contribution and role for the life of the nation. In the aspect of community empowerment, especially the role in eradicating poverty and economic empowerment through alms and donations, Tarmizi Taher participates in contributing ideas and real work through sharing forums that are carried out or through strengthening non-governmental organizations.

\subsection{Empowerment of Community Economic}

Tarmizi Taher is a national leader who does not only think about one scientific field and life issues that exist in society, but he has exceeded many fields that could contribute a lot to solving the problems faced by this nation. A unique and multitalented figure is a real portrait of his work in contributing and contributing to the progress of the nation in the future. One tangible form of his thoughts and contributions to this nation is his attention to the problem of empowering the people through economic development and poverty alleviation efforts that are still rampant in the lives of Indonesian people.

Before further discussing Tarmizi Taher's progress in the economic empowerment of the people, it is first important to explain how the portrait of Indonesian people's lives are required to live independently and be more productive in establishing businesses or businesses in order to overcome gaps and poverty that are increasingly rampant in the life of the nation and state. This has become important to encourage the community to be more independent in developing their business and economy in a better direction.

The independence of our nation can only be done by building a culture of entrepreneurship. Likewise with a nation that is in a puddle and a pool of slump, it can only be removed by building a culture of independence. If in the family, our children are implanted with a culture of independence from an early age, then it is possible that when they reach adulthood, they will be able to build their own businesses.

As a policy controller, the government plays a major role in supporting funds and subsidies to disadvantaged communities and also providing employment opportunities and opportunities for them in a sustainable manner. Do not let their rights and rights are

\footnotetext{
${ }^{3}$ D. Hendropuspito, Sosiologi Agama, (Yogyakarta; Kanisius, 2000), pp. 172-175
} 
neglected, let alone to disrupt the business activities they build, such as by carrying out evictions of their workplaces.

We must indeed admit that the more rapid advances in technology and the latest science, community empowerment promoted by the government has experienced significant changes, even arguably in progress beyond the limits of human capability. That success, we can see from improving the standard of living of the community in undergoing life competition and increasingly complex future challenges. Although not all of them are fully felt by the community, at least they have shown a more promising and increasing performance for the development of a just and prosperous society.

Community empowerment as an application of government programs requires full enthusiasm from the community itself so that they will make every effort to improve the quality of their human resources in a total and continuous manner. Many efforts have indeed been carried out by the government, one of which is by providing assistance which is directly channeled to remote villages to support village development and the development of local potentials that are undoubtedly empowered.

That is why, community empowerment which is the government's top priority, is believed to have considerable benefits for the development of the rural economy, where the level and level of the economy is still very weak. Recognizing the importance of improving the standard of living of the people, careful preparation is needed to welcome the era of industrialization which offers much progress for the survival of the human race. In the midst of the tantrums and the onslaught of globalization too, we need to prepare ourselves to fend off all incoming currents and ideologies that disrupt the minds of our young people. The preparation can be started by improving the quality of education, culture, and developing local potentials that are creative, potential, and skilled in improving the work ethic of society in this era of industrialization development.

Various ways that have been carried out by the government in empowering the common people are felt to be very important in facing life competition and tight global markets that present certain missions in the joints of universal life. Empowering small communities through improving the quality of human resources becomes a fundamental value for the creation of more mature community buildings. When the quality of human resources becomes more adequate and inherent in the character of each community, then the standard of living of the community will increasingly show a more promising performance.

Then what about the Tarmizi Taher view related to the importance of economic empowerment for increasing the welfare of the people who are increasingly experiencing uncertainty? For Tarmizi Taher, the economic empowerment of the people is an important capital in the efforts to alleviate poverty that occur in the life of society as a whole. So the movement to find a solution to the problem is very important to do, both in the form of an economic movement to help the weak in order to improve their lives so that life is more decent.

Tarmizi Taher has the view that Muslims must not be shackled by economic difficulties and must try hard to be able to survive with adequate work spirit. ${ }^{4}$ This is because, Islam as a religion does not want its people to just relax and enjoy life without trying hard to sustain

\footnotetext{
${ }^{4}$ Nurul Badrut Tamam, "Dakwah Islam di Tengah Tantangan Globalisasi: Pemikiran dan Kontribusi Tarmizi Taher”, dalam Heru Sucipto (ed.), Islam Mazhab Tengah, (Jakarta,Grafindo, 2007), p. 331.
} 
their lives. In fact, Islam encourages all people to unite to overcome various problems of life, including economic problems that often become obstacles in reaching a better life.

As a national figure, Tarmizi Taher has an extraordinary concern and concern for the nation's people so that he must come down directly in overcoming the problem. For Tarmizi Taher, Muslims should not just stand idle and mourn a difficult life. They must have the ability to find out the causes of life gaps and uncertainties in the dynamics of public life in general. This is done to determine the steps and decisions in solving problems that occur in order to find the right solution in empowering the community.

\subsection{Poverty Alleviation as a Social Disease}

Tarmizi Taher as a national figure also has an interest in the problem of national poverty which is indeed a common problem in reaching better national and state life. The problem of poverty is the problem of all humanity, because anyone must be in touch with the issue and problem of poverty so they must care in overcoming poverty in people's lives.

Before further discussing Tarmizi Taher's view of his work in overcoming poverty, it is important to explain the root problem of poverty itself, which is often the problem of every nation's children in various aspects of life. The problem of poverty that befalls the Indonesian people cannot be left alone, because it involves the interests and problems of many people. This problem must require an alternative strategy so that poverty that strikes various development sectors, including the problem of social inequality that often occurs in people's lives.

Poverty is part of the social ills that afflict every child of the nation from various regions so that it must be immediately addressed with a good path and a capable strategy so that there is no harmony in the matter of handling. In overcoming poverty, it is not only enough to provide capital or money directly to the community, but also given adequate education and skills so that they can develop their creativity and skills in accordance with their expertise. So efforts are needed to strengthen the culture of entrepreneurship so that our young generation is able to become an independent child of the nation without having to shoulder the burden of the country's debt and the burden of its own life.

Poverty is our common problem and should not be used as a tool or commodity in taking advantage of every nation's problems. Entrepreneurship culture is one of the best ways that can be done to overcome unemployment for college graduates and the problem of poverty that afflicts people's lives. This is because, a nation that is in a pool of slump, poverty, inequality, and unemployment, can only be overcome by building a culture of independence or an entrepreneurial culture in the midst of society.

In a broader context, the problem of poverty is a matter of how people can adapt to technological advances in order to be able to design and be able to survive in the midst of globalization. Then economic growth in people's lives becomes one of the absolute requirements so that a nation or society can be separated from the poverty gap and social inequalities that occur in a broader context. The loss of the entrepreneurial attitude of the people of a nation can be fatal to the stagnation of the nation's economic growth, even though they master the factors of production.

An entrepreneur is a person who has the ability to be independent and have a career in the future, balanced by motivation, vision, communication, optimism, and the ability to take advantage of opportunities in business. The spirit and hard work in this case become a permanent character of an entrepreneur, because the vision put forward is how to build a 
bright future and be free from problems of unemployment and poverty. That is the reason why entrepreneurship is an alternative way to overcome various national problems, especially the problem of poverty, which until now has not shown optimal results.

Then what about the Tarmizi Taher view of poverty alleviation that has engulfed the life of the nation and state? By referring to Tarmizi Taher's view, we can take inspiration from all thoughts and actions taken by promoting the spirit of togetherness and brotherhood in overcoming the problems of the nation. Through his organization, Tarmizi Taher has a strong desire and desire to eradicate the poverty of the people which is indeed a crucial problem in the life of the nation and state.

Tarmizi Taher has the view that poverty is not always related to poverty in material or material aspects, but there are many aspects of poverty that are a problem in the lives of people, such as poor knowledge or other matters relating to poverty. The breadth of poverty coverage indicates that poverty is a problem for every people from various aspects of life, from the economy, education, politics, culture, even to religion.

\subsection{Social and Community Empowerment}

The most important agenda in community empowerment according to Tarmizi Taher is the importance of social and community empowerment which is a reflection of wider community welfare. According to Tarmizi Taher, one of the dimensions of preaching that is often forgotten is the agenda of social and social empowerment. This agenda concerns the problem of the inability of the community to properly utilize technological developments and science.

In Tarmizi Taher's view, community empowerment can be done by providing skills education conducted by the government so that people can compete with the advancement of science and technology. The community must be empowered with a variety of social and educational programs that encourage their enthusiasm and confidence in working and produce something that is beneficial for social change in the midst of society.

So the duty of a preacher is also to convey a message about the importance of being active in social activities for the benefit of a better society. The community must be encouraged and encouraged to have the passion to make changes in themselves and others so that they can produce greater social change for the interests of the nation and state.

\section{Conclusion}

In Tarmizi Taher's view, community empowerment can be done by providing skills education conducted by the government so that people can compete with the advancement of science and technology. The community must be empowered with a variety of social and educational programs that encourage their enthusiasm and confidence in working and produce something that is beneficial for social change in the midst of society.

So the duty of a preacher is also to convey a message about the importance of being active in social activities for the benefit of a better society. The community must be encouraged and encouraged to have the passion to make changes in themselves and others so that they can produce greater social change for the interests of the nation and state. 


\section{References}

Abdul. Karim. (2010). Politik Kebijakan Tarmizi Taher: Menteri Agama RI Periode 19931998. Yogyakarta: Suka Press.

Abdurrahman, Mas'ud. and Salim, Ruhana. (2012). Kompilasi Kebijakan dan Peraturan Perundang-Undangan Kerukunan Umat Beragama, (Jakarta: Puslitbang Kehidupan Keagamaan.

D. Hendropuspito. (2000). Sosiologi Agama. Yogyakarta; Kanisius.

Humaidy, Abdussami and Masnun Tahir. (2007). Islam dan Hubungan Antar Agama. Yogyakarta: LKSI.

Heru, Sucipto. (2007). Islam Mazhab Tengah: Persembahan 70 Tahun Tarmizi Taher. Jakarta: Grafindo.

Ibnu, Katsir, Tafsir al-Qur'an al-Azhim,. t.tp: Daar al-Rashaad al-Hadiithah, t.th.

Irwan, Masduqi. (2010). Berislam Secara Toleran. Bandung: Mizan.

Komarudin, Hidayat. (2002). Wahyu di Langit Wahyu di Bumi: Doktrin dan Peradaban Islam di Panggung Sejarah. Jakarta: Paramadina.

Mohamed Fathi Osman. (2006). Islam, Pluralisme, dan Toleransi Keagamaan: Pandangan al-Qur'an, Kemanusiaan, Sejarah, dan Peradaban. Jakarta: PSIK Universitas Paramadina.

Nurul Badrut Tamam. (2007). Dakwah Islam di Tengah Tantangan Globalisasi: Pemikiran dan Kontribusi Tarmizi Taher in Heru Sucipto (ed.), Islam Mazhab Tengah, Jakarta, Grafindo.

Suf, Kasman. (2004). Jurnalisme Universal: Menelusuri Prinsip-Prinsip Dakwah bi alQalam dalam al-Qur'an. Jakarta: Teraju.

Zakiyuddin Baidhawi. (2005). Kredo Kebebasan Beragama. Jakarta: PSAP. 